\title{
Medical Treatment for Patients from Remote Islands in the Department of Otolaryngology Tokyo Metropolitan Hospital
}

\author{
Takao Yabe, Yuka Nakamura and Kazunari Okada
}

\begin{abstract}
Our Department is responsible for medical treatment in the Tokyo metropolitan area and IzuOgasawara islands. One hundred fifty nine referred patients from the medical institution of Izu-Ogasawara islands in the last five years were investigated based on their medical records. Thirty two patients a year visited our department, consisting of 66 females and 93 males aged 1 to 90 years with a mean of 56. 4 years. Complications of lifestyle-related disease such as hypertension and diabetes mellitus were recognized in $43 \%$ and ear diseases were most frequent. Four cases (3\%) were transported by emergency, which comprised 2 cases of acute epiglottitis, one case of severe massive epistaxis and one case of acute tonsillitis. Twenty seven cases (17\%) were hospitalized immediately and 23 cases needed surgical treatments, comprising 4 tympanoplasties, 3 adenotonsillectomies, 3 tonsillectomies, 3 endoscopic sinus surgeries and 2 parotidectomies.
\end{abstract}

Keywords : emergent diseases in otolaryngology, medical image transmission system, medical treatment in a remote island, rural area medicine

\section{References}

1）坂田 正：瀬戸内海島嶼の一農業部落に多発した聾喂とそ の家系について。聑鼻会報 59: 1803-1811, 1956.

2) 村島二郎, 西田裕明, 山口良二：離島に㧍ける耳鼻咽喉科 診療. 耳鼻咽喉 46: 191-194, 1974.

3) Shirabe $S$ : The state of vertiginous lesions in Tsushima Island. Pract Otol (Kyoto) 76: 2211-2214, 1983.

4）山口 隆, 坂口 寛, 中島成人, 他 : ティンパノメトリー を用いた園児滲出性中耳炎のスクリーニングについて一厳 原町と長崎市での比較一. Otol Jpn 3: 162-167, 1993.

5）高崎賢治, 寺門万里子, 高橋晴雄：長崎県離島におけるス ギ花粉症の疫学調查一平戸市大島村全島民へのアンケート 調查から一. 日鼻科会誌 49: 112-115, 2010.

6) Nobori T, Ohyama M, Katsuta K, et al. : Clinical and epidemiological studies of nasal allergy. Pract Otol (Kyoto) 77: 737$747,1984$.

7）河野正樹：離島診療所で経験した耳鼻咽喉科疾患症例の検 討. 日耳鼻会報 94：203-207, 1991 .
8) Nagano $\mathrm{H}:$ A case of epiglottitis associated with Tsutsugamushi disease. Pract Otol (Kyoto) 99: 955-959, 2006.

9）永野広海, 吉福孝介, 大野郁夫, 他：離島における耳鼻咽 喉科・頭頸部外科の役割と現状一鹿児島県奄美諸島の場合 一. 地域医学 22: 628-633, 2008.

10) Nagano $H$ and Kurono $Y$ : The frequency and severity of subclinical hypogeusia in the general community. Pract Otol (Kyoto) 105: 33-40, 2012.

11）長嶺功一：ヘリ等, 航空機搬送患者資料. 沖縄那覇病誌 8: 52-54, 1998.

12）石川浩太郎, 玉川雄也, 阿部弘一, 他 : 医療過疎地におけ る総合医の耳鼻咽喉科診療. 日耳鼻会誌 99：1758-1763, 1996.

13）今道英秋：眼科・耳鼻咽喉科救急を考える 離島・へき地 で対応すべき眼科・耳鼻咽喉科の救急疾患. 救急医療ジャー ナル 16: 14-17, 2008.

14）大平泰行, 矢部多加夫, 加我君孝, 他：職業潜水夫と耳科 疾患について一耳科症状と耳管機能検查を中心に一. 耳鼻・ 頭頸外科 63: 13-17, 1991.
Department of Otolaryngology, Tokyo Metropolitan Hiroo Hospital
Corresponding Author Address : Takao Yabe

takao_yabe@tmhp.jp 


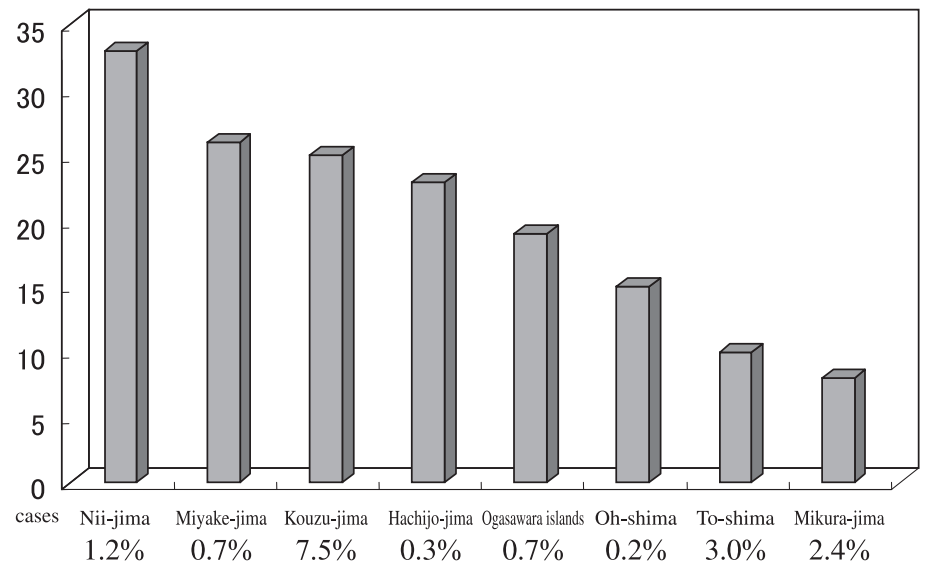

Islands the patients were referred from:

Numbers of the patients are shown in the order of their location, namely Nii-jima, Miyake-jima, Kouzu-jima, Hachijo-jima, Ogasawara islands, Oh-shima, To-shima and Mikura-jima.

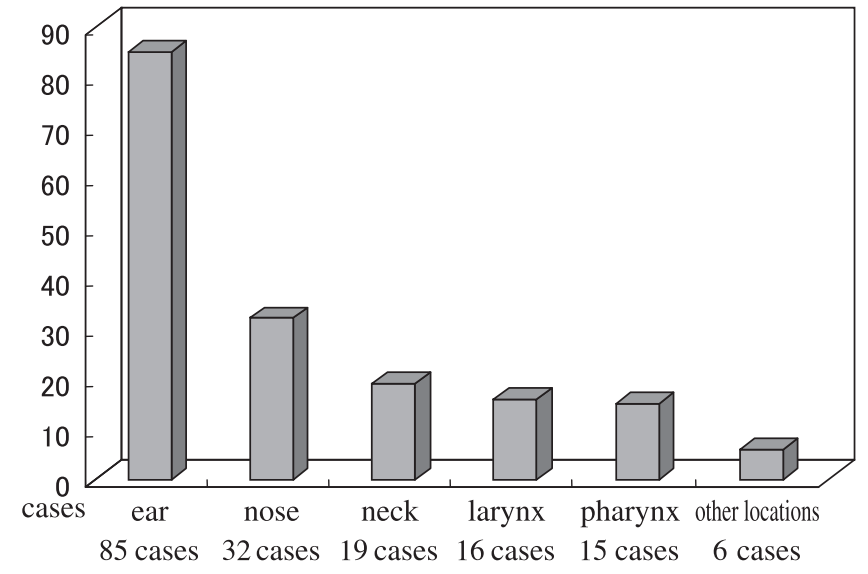

Diseases

The disease sites are frequent in the order of ear, nose, neck, larynx, pharynx and other locations. 